$1989,38,2$

УдК 541. II

L. KUDRYAVTSEVA, M. KUUS, Helle KIRSS, I. VINK

\title{
EFFECT OF MOLECULAR STRUCTURE ON THE EXCESS ENTHALPIES OF MIXTURES WITH UNSATURATED HYDROCARBONS
}

\author{
(Presented by $O$. Eisen)
}

In this work excess enthalpies, $H^{E}$, for unsaturated hydrocarbon mixtures with some solvents of different polarity have been measured. We aimed at making a comparison between experimental results for the binary mixtures containing unsaturated hydrocarbons of different structure.

A survey of literature revealed that experimental data are very scarce for this class of mixtures. At present the lack of suitable experimental results hinders the interpretation and prediction of $H^{E}$ for the above mixtures using the models under development.

\section{Experimental}

The procedure using a differential microcalorimeter has been described in [ $\left.{ }^{1}\right]$. The errors of the observed values were lower than 2 per cent over the whole mole fraction range. For all the mixtures investigated in this work, except 2-octyne-1-octanol, $H^{E}$ was measured at $298.15 \mathrm{~K}$ only and at atmospheric pressure. For the 2-octyne-1-octanol mixtures the results at $318.15 \mathrm{~K}$ have been given too.

cis-4-Octene, methylcyclohexene, ethylcyclopentene, butylcyclopentene and isomeric octynes were synthesized in our laboratory* and fractionally distilled in a 50-plate Teflon bristle-rotor column [ $\left.{ }^{2}\right]$ to 98,6 per cent and higher purrity as detected by gas liquid chromatography on PEG-20M and Squalan capillary columns using $\mathrm{H}$ flame ionization detector. Reference should be made to earlier papers $\left.{ }^{3-5}\right]$.

$n$-Heptane, $n$-nonane, 1-propanol («puriss grade») were purchased from Reakhim (USSR) and used without further purification.

Cyclohexane, 1-butanol, 2-propen-1-ol, 1-octanol, ketones and dimethyl sulphoxide («pure grade») were twice fractionally distilled with the same column to 99.8 per cent and higher estimated from their capillary chromatograms.

\section{Results and discussion}

Table 1 presents experimental results for the molar excess enthalpies of the 24 binary systems formed by mixing methylcyclohexene and ethylcyclopentene with $n$-heptane, butylcyclopentene with $n$-nonane, cis-4-octene and methylcyclohexene with cyclohexane, 1-octene and 1-octyne with ethylbenzene, methylcyclohexene, 1-octene, 1-octyne and 2-octyne with methyl butyl ketone, 1-octene with methyl isobutyl ketone, 1-octene with

\footnotetext{
* The laboratory of physicochemical investigations.
} 
Experimental excess molar enthalpies $H E\left(\mathrm{~J} \cdot \mathrm{mol}^{-1}\right)$ at $298.15 \mathrm{~K}$

\begin{tabular}{|c|c|}
\hline$x_{1}$ & $H E$ \\
\hline \multicolumn{2}{|c|}{$\begin{array}{l}\text { 1-Methylcyclohexene (1 } \\
n \text {-heptane (2) }\end{array}$} \\
\hline 0.104 & 33 \\
\hline 0.192 & 63 \\
\hline 0.255 & 64 \\
\hline 0.320 & 75 \\
\hline 0.417 & 94 \\
\hline 0.468 & 98 \\
\hline 0.532 & 86 \\
\hline 0.735 & 80 \\
\hline 0.884 & 38 \\
\hline \multicolumn{2}{|c|}{$\begin{array}{l}\text { 1-Ethylcyclopentene (1 } \\
n \text {-heptane (2) }\end{array}$} \\
\hline 0.071 & 18 \\
\hline 0.123 & 30 \\
\hline 0.173 & 40 \\
\hline 0.270 & 54 \\
\hline 0.370 & 65 \\
\hline 0.445 & 74 \\
\hline 0.498 & 75 \\
\hline 0.604 & 73 \\
\hline 0.605 & 72 \\
\hline 0.614 & 73 \\
\hline 0.670 & 62 \\
\hline 0.716 & 58 \\
\hline 0.944 & 9 \\
\hline
\end{tabular}

3. 1-Butylcyclopentene (1) $n$-nonane (2)

$\begin{array}{ll}0.114 & 31 \\ 0.146 & 34 \\ 0.152 & 34 \\ 0.242 & 50 \\ 0.361 & 62 \\ 0.466 & 68 \\ 0.517 & 68 \\ 0.654 & 63 \\ 0.722 & 55 \\ 0.854 & 34 \\ 0.886 & 31 \\ 0.970 & 8\end{array}$

4. 1-Methylcyclohexene (1)cyclohexane (2)

$\begin{array}{lr}0.125 & 63 \\ 0.216 & 106 \\ 0.363 & 118 \\ 0.469 & 134 \\ 0.552 & 127 \\ 0.570 & 120 \\ 0.750 & 87 \\ 0.870 & 45\end{array}$

5. cis-4-Octene (1)-cyclohexane (2)

$\begin{array}{ll}0.146 & 117 \\ 0.184 & 129 \\ 0.189 & 133 \\ 0.262 & 158 \\ 0.403 & 168 \\ 0.411 & 174 \\ 0.474 & 168 \\ 0.490 & 168\end{array}$

$x_{1}$

$H E$

$x_{1}$
11. 1-Octyne (1) - methyl butyl ketone (2)
0.152
0.176
$-96$

0.576

164

0.672

119

0.756

89

6. 1-Octene (1) - ethylbenzene (2)

\begin{tabular}{lr||rr}
0.065 & 60 & 0.616 & -113 \\
0.136 & 148 & 0.733 & -87
\end{tabular}

0.136

193

0.198

215

0.340

277

0.438

297

0.469

296

0.523

299

0.602

281

0.676

253

0.680

239

0.718

231

0.814

164

0.880

110

7. 1-Octyne (1) - ethylbenzene (2)

$\begin{array}{ll}0.087 & -15 \\ 0.174 & -25 \\ 0.270 & -33 \\ 0.352 & -38 \\ 0.481 & -41 \\ 0,590 & -40 \\ 0.674 & -33 \\ 0.802 & -24 \\ 0.821 & -22\end{array}$

8. 1-Octene (1)-methyl butyl ketone (2)

$\begin{array}{ll}0.360 & 640 \\ 0.405 & 706 \\ 0.520 & 753 \\ 0.543 & 755\end{array}$

9. 1-Octene (1)-methyl isobutyl ketone(2)

$\begin{array}{ll}0.126 & 298 \\ 0.176 & 366 \\ 0.300 & 565 \\ 0.322 & 612 \\ 0.556 & 705 \\ 0.611 & 688 \\ 0.716 & 643 \\ 0.748 & 603 \\ 0.851 & 457\end{array}$

10. 1-Methylcyclohexene (1) methyl butyl ketone (2)

$0.142 \quad 250$

$\begin{array}{ll}0.225 & 383\end{array}$

$0.414 \quad 573$

$\begin{array}{ll}0.509 & 587\end{array}$

\begin{tabular}{l|l}
0.590 & 649
\end{tabular}

$0.727 \quad 580$
0.863

0.863
12. 2-Octyne (1) - methyl butyl ketone (2)

$\begin{array}{lr}0.114 & 76 \\ 0.178 & 144 \\ 0.199 & 152 \\ 0.244 & 193 \\ 0.373 & 267 \\ 0.609 & 308 \\ 0.628 & 303 \\ 0.694 & 284 \\ 0.836 & 190 \\ 0.886 & 155\end{array}$

13. 1-Octyne (1)-1-propanol (2)

$\begin{array}{ll}0.514 & 909 \\ 0.533 & 936 \\ 0.595 & 961 \\ 0.717 & 940\end{array}$

14. 1-Octene (1)-2-propen1-ol(2)

$\begin{array}{ll}0.141 & 414 \\ 0.318 & 577 \\ 0.436 & 786 \\ 0.543 & 813 \\ 0.554 & 849 \\ 0.572 & 865 \\ 0.785 & 782 \\ 0.866 & 659\end{array}$

15. 1-Butylcyclopentene (1)1-butanol (2)

$\begin{array}{lr}0.055 & 72 \\ 0.270 & 378 \\ 0.401 & 506 \\ 0.490 & 581 \\ 0.501 & 584 \\ 0.706 & 627 \\ 0.859 & 460\end{array}$

16. 1-Octyne(1)-1-butanol (2)

$\begin{array}{lr}0.112 & 230 \\ 0.247 & 524 \\ 0.395 & 805 \\ 0.515 & 948 \\ 0.555 & 977 \\ 0.615 & 1017 \\ 0.730 & 990 \\ 0.798 & 888 \\ 0.954 & 379 \\ 0.981 & 237 \\ 0.990 & 155\end{array}$




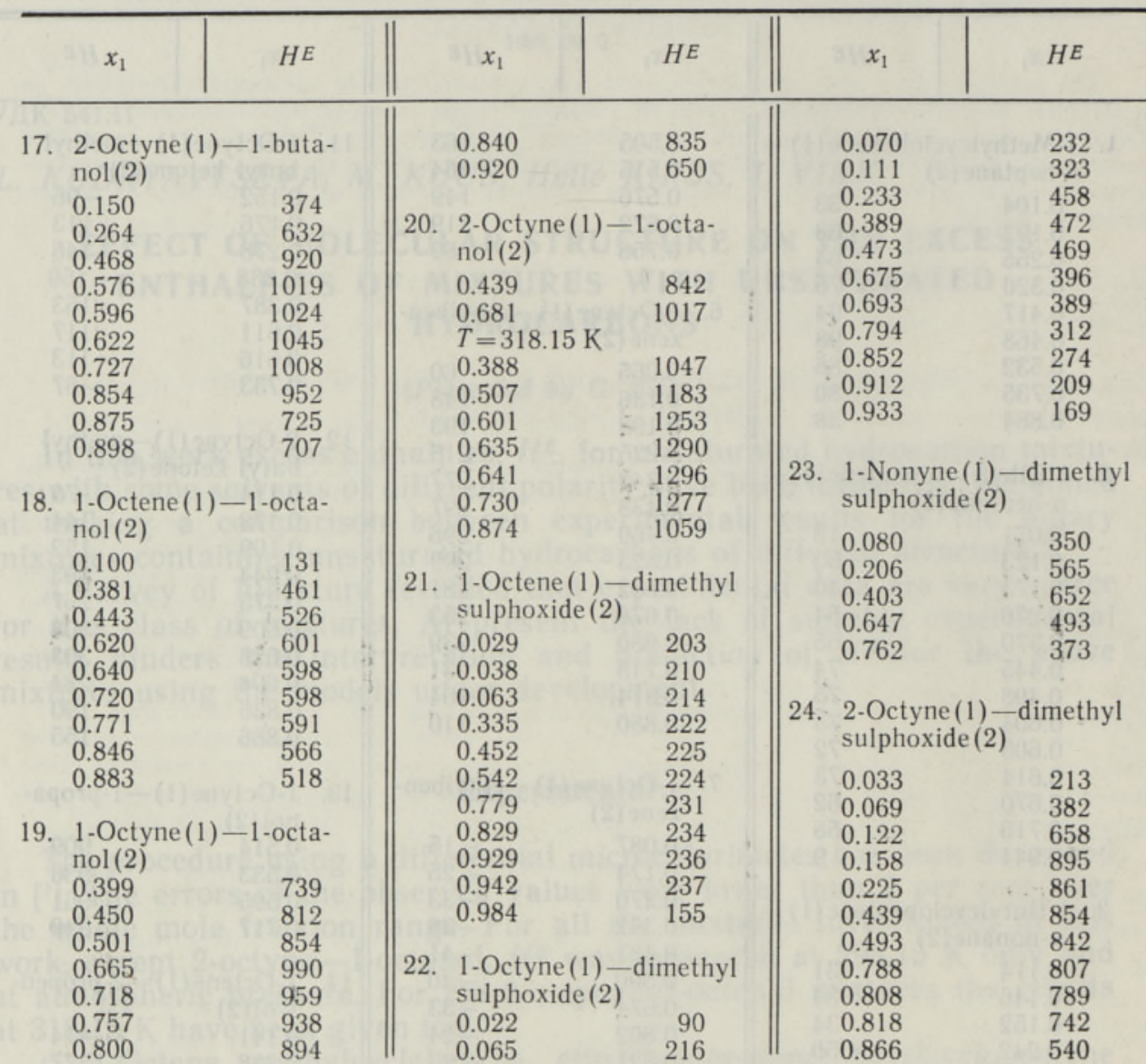

2-propen-1-ol, 1-octyne with 1-propanol, butylcyclopentene, 1-octyne and 2-octyne with 1-butanol, 1-octene, 1-octyne and 2-octyne with 1-octanol, 1-octene, 1-octyne, 2-octyne and 1-nonyne with dimethyl sulphoxide (DMS). In all cases $x_{1}$ denotes the mole fraction of unsaturated hydrocarbon in the binary.

The results were fitted with the following equation

$$
H^{E}\left(\mathrm{~J} \cdot \mathrm{mol}^{-1}\right)=x_{1} x_{2} \sum_{p=1}^{n} A_{p}\left(x_{1}-x_{2}\right)^{p-1} .
$$

The values of the coefficients $A_{p}$, determined by the least squares method, and standard deviation $\sigma$ are summarized in Table 2. Smooth representations of the results and experimental points for systems with cyclohexane, ketones, alkanols and DMS are also presented in Figs 1-4 together with the curves and points taken from our previous works [ ${ }^{6,7}$ ] (Figs 1 and $3 b$ ).

In our earlier work we have measured the excess enthalpies of $n$-alkane mixtures with $n$-alkenes and $n$-alkynes $[1,8,9]$. The excess enthalpies of the alkyl cyclene mixtures with $n$-alkane (Table 1 , Nos $1-3$ ) with a given number of carbon atoms are higher than those of $n$-alkene mixtures $\left(H^{E}{ }_{x=0.5}=49 \mathrm{~J} \cdot \mathrm{mol}^{-1}\right.$ for 1-heptene- $n$-heptane [ $\left.\left.{ }^{9}\right]\right)$ and much lower than those of $n$-alkyne mixtures $\left(H^{E}{ }_{x=0.5}=555 \mathrm{~J} \cdot \mathrm{mol}^{-1}\right.$ for 1 -heptyne- $n$-heptane $\left.\left[{ }^{8}\right]\right)$. In such systems, with increasing number of carbon atoms in the cyclene molecule the $H^{E}$ increases. The opposite is observed with the cyclene alkyl length. 
Parameters $A_{P}$ of equation (1) and standard deviations $\sigma^{*}$

\begin{tabular}{|c|c|c|c|c|c|}
\hline System & $A_{0}$ & $A_{1}$ & $A_{2}$ & $A_{3}$ & $\sigma$ \\
\hline 1-Methylcyclohexene (1) - n-heptane (2) & 380.0 & 49.6 & -12.0 & -73.6 & 6.5 \\
\hline 1-Ethylcyclopentene (1) - n-heptane (2) & 301.9 & 4.1 & -95.2 & -72.2 & 2.9 \\
\hline 1-Butylcyclopentene (1) $-n$-nonane (2) & 271.2 & 31.6 & 20.9 & -60.7 & 1.9 \\
\hline 1-Methylcyclohexene (1) - cyclohexane (2) & 520.1 & 124.0 & -34.0 & 3.7 & 7.1 \\
\hline cis-4-Octene $(1)$-cyclohexane $(2)$ & 658.2 & -277.2 & -31.4 & -231.8 & 2.4 \\
\hline 1-Octene (1) - ethylbenzene (2) & 1213.6 & -230.8 & -195.1 & 316.9 & 6.8 \\
\hline 1-Octyne (1) - ethylbenzene (2) & -162.6 & 10.8 & 3.7 & 24.2 & 1.1 \\
\hline 1-Octene (1) -methyl isobutyl ketone(2) & 2801.3 & 385.5 & 640.0 & 601.8 & 13.7 \\
\hline $\begin{array}{l}\text { 1-Methylcyclohexene(1) - methyl butyl } \\
\text { ketone(2) }\end{array}$ & & 670.5 & 642.0 & 601.4 & 20.9 \\
\hline 1-Octyne(1) - methyl butyl ketone (2) & -564.1 & 410.3 & -125.1 & -445.7 & 3.0 \\
\hline 2-Octyne(1) - methyl butyl ketone (2) & 1243.7 & 188.8 & -167.6 & 470.5 & 6.2 \\
\hline 1-Butylcyclopentene (1)-1-butanol(2) & 2345.3 & 1185.8 & 712.3 & 651.5 & 5.7 \\
\hline 1-Octene $(1)-1$-octanol (2) & 2141.1 & 678.8 & 1855.6 & 2625.5 & 20.5 \\
\hline 1-Octyne(1)-1-butanol(2) & 374 & 2085.0 & 986.8 & 872.9 & 5.9 \\
\hline 2-Octyne(1)-1-butanol(2) & 380 & 1822.4 & 2225.7 & 1972.4 & 49.5 \\
\hline 1-Octyne (1)-dimethyl sulphoxic & & & 1860.1 & 3.5 & 12.8 \\
\hline 2-Octyne (1)-dimethyl sulphoxide (2) & 5268.8 & -1874.1 & 876.5 & 1811.0 & $33.4^{* *}$ \\
\hline
\end{tabular}

* For alkanol systems for $x_{1}=0$ to 0.9 only.

** For homogeneous region only.

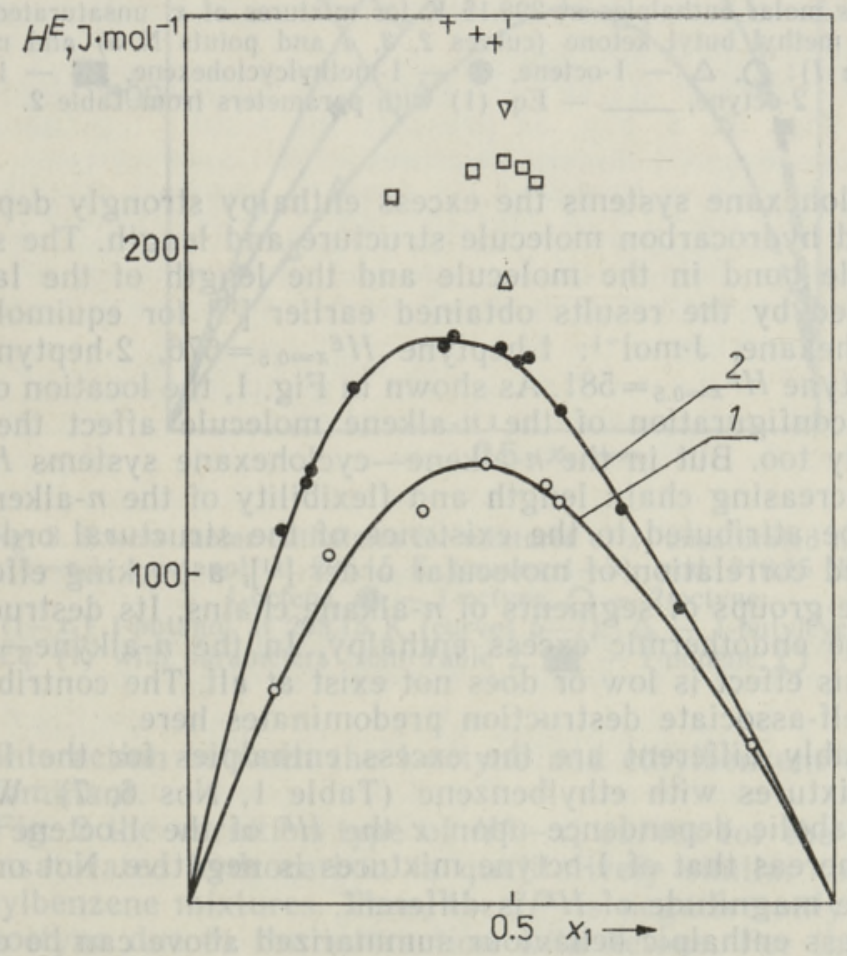

Fig. 1. Excess molar enthalpies at $298.15 \mathrm{~K}$ for mixtures of $x_{1}$ unsaturated hydrocarbons with $\left(1-x_{1}\right)$ cyclohexane: - cis-4-octene (curve 2), O-1-methylcyclohexene (curve 1), $\Delta$ - trans-4-octene [ $\left.{ }^{6}\right], \square-1$-heptene $\left[{ }^{6}\right], \Delta-1$-octene $\left[{ }^{6}\right],+-1$-nonene [ๆ], _ — Eq. (1) with parameters from Table 2. 


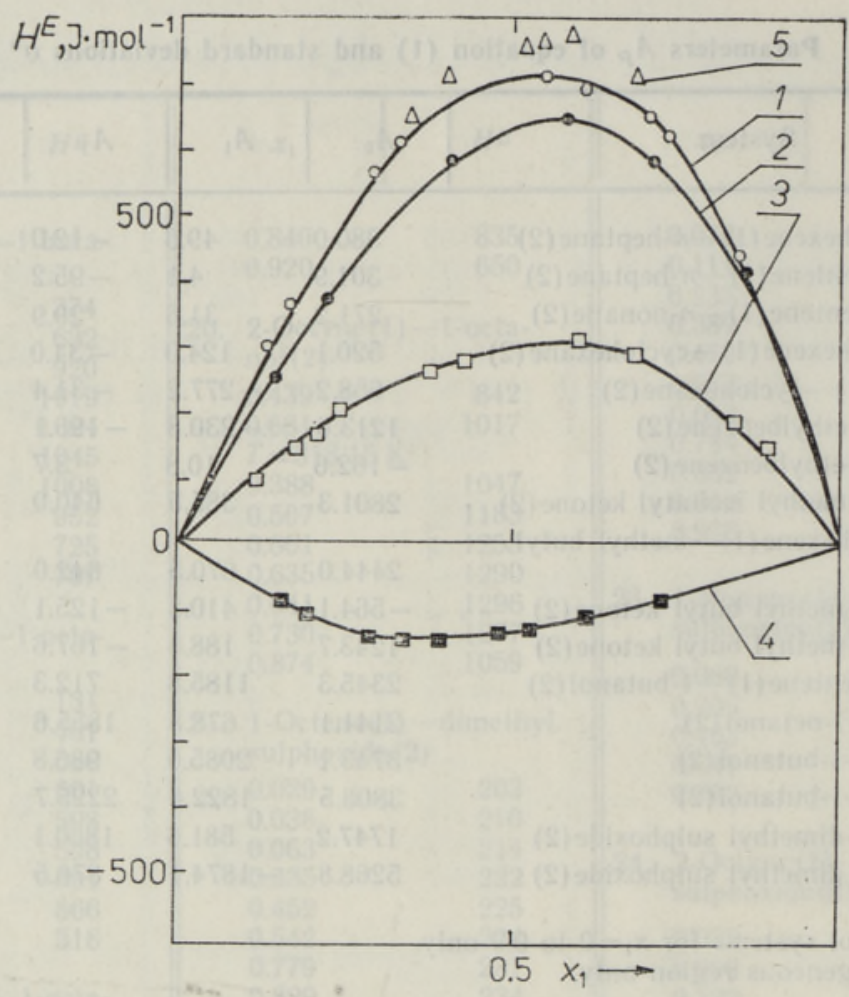

Fig. 2. Excess molar enthalpies at $298.15 \mathrm{~K}$ for mixtures of $x_{1}$ unsaturated hydrocarbons with $\left(1-x_{1}\right)$ methyl butyl ketone (curves 2, 3, 4 and points $N$ 5) and methyl isobutyl ketone (curve 1 ): $0, \Delta-1$-octene, - 1-methylcyclohexene,

2-octyne, _ — Eq. (1) with parameters from Table 2.

For cyclohexane systems the excess enthalpy strongly depends on the unsaturated hydrocarbon molecule structure and length. The strong effect of the triple bond in the molecule and the length of the latter can be demonstrated by the results obtained earlier $\left[{ }^{10}\right]$ for equimolar mixtures with cyclohexane, $\mathrm{J} \cdot \mathrm{mol}^{-1}$ : 1-heptyne $H^{E} x_{x=0.5}=676$, 2-heptyne $H^{E}{ }_{x=0.5}=$ $=515$, 1-octyne $H^{E}{ }_{x=0.5}=581$. As shown in Fig. 1, the location of the double bond and configuration of the $n$-alkene molecule affect the $H^{E}$ values significantly too. But in the $n$-alkene-cyclohexane systems $H^{E}$ increases with the increasing chain length and flexibility of the $n$-alkene molecule. This may be attributed to the existcnce of the structural ordering effect, the so-called correlation of molecular order [ $\left.{ }^{11}\right]$, a packing effect favoured between the groups of segments of $n$-alkane chains. Its destruction contributes to the endothermic excess enthalpy. In the $n$-alkyne-cyclohexane mixtures this effect is low or does not exist at all. The contribution of the $n$-alkyne self-associate destruction predominates here.

Remarkably different are the excess enthalpies for the 1-octene and 1-octyne mixtures with ethylbenzene (Table 1, Nos 6, 7). With a more or less parabolic dependence upon $x$ the $H^{E}$ of the 1-octene mixtures is positive, whereas that of 1-octyne mixtures is negative. Not only the sign but also the magnitude of $H^{E}$ is different.

The excess enthalpic behaviour summarized above can be qualitatively explained by postulating that $H^{E}$ is the resultant of two opposing effects: the breaking of self-associates and structural order leads to endothermic contribution and the exothermic one arises from interactions between unlike molecules. In the 1-octyne-ethylbenzene system the contribution 


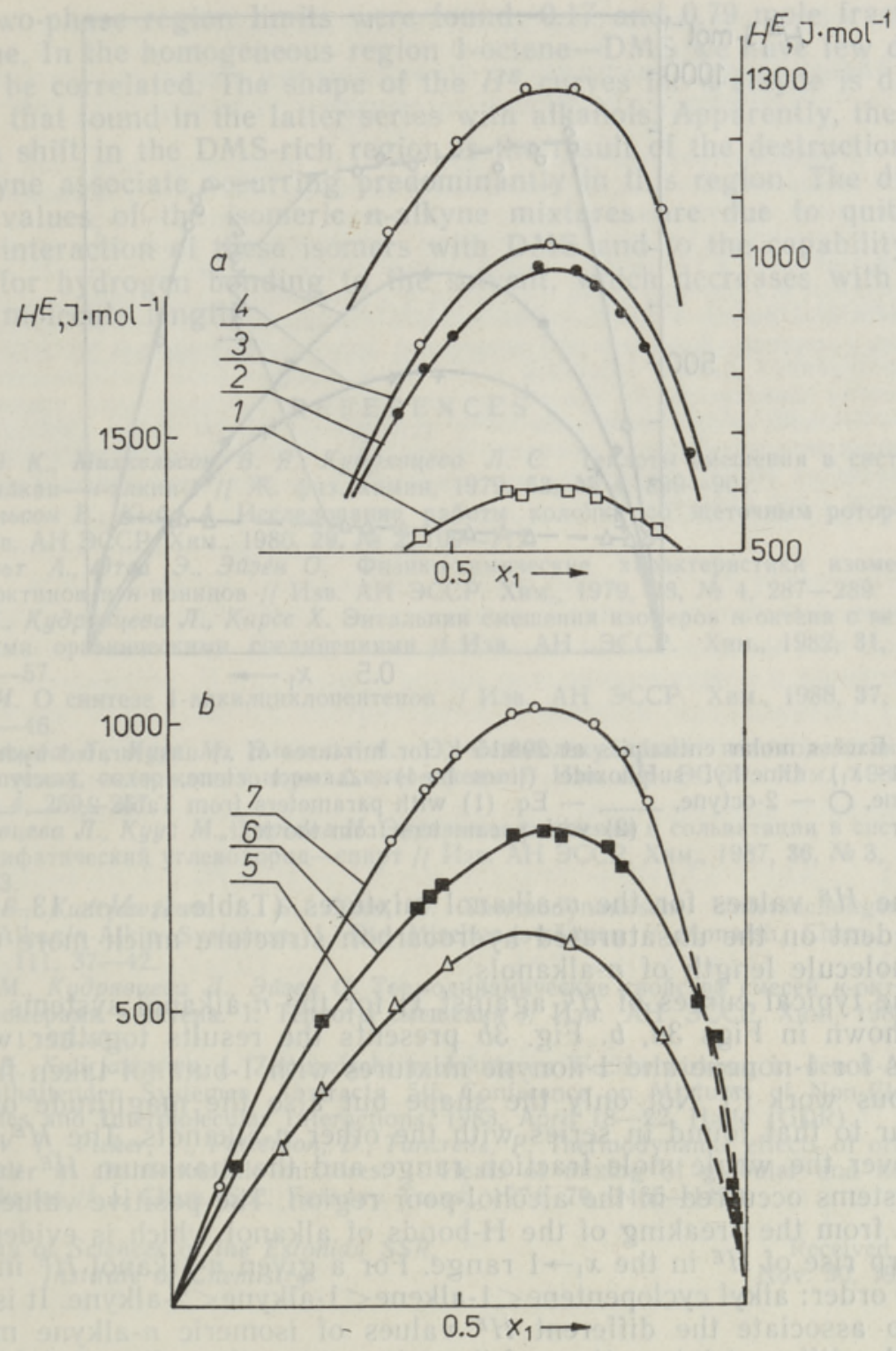

Fig. 3. Excess molar enthalpies for mixtures of $x_{1}$ unsaturated hydrocarbons a) with $\left(1-x_{1}\right) \quad 1$-octanol at $298.15 \mathrm{~K}$ (curves $1-3$ ) and $318.15 \mathrm{~K}$ (curve 4):

b) with $\left(1-x_{1}\right)$ 1-butanol at $298.15 \mathrm{~K}$ (curves $\left.5-7\right): \triangle-1$-butylcyclopentene,

Eq. (1) with parameters from Table 2, -1 -nonene, $\mathrm{A}-1$-nonyne.

of the interaction between the 1-octyne and ethylbenzene molecules to $H^{E}$ is predominant.

In Fig. 2 the variation type of $H^{E}-x_{1}$ curves for the ketone mixtures with unsaturated hydrocarbon is qualitatively similar to that found for the ethylbenzene mixtures. Thus, the $H^{E}$ is negative only for the mixture with 1-octyne due to the interaction with ketone. For the mixtures with other components the $H^{E}$ is positive, decreasing in the order 1-octene> $>$ methylcyclohexene $>2$-octyne. The positive values of $H^{E}$ in the 2-octyne mixtures result from the breaking of associates which predominates over the whole concentration range. 


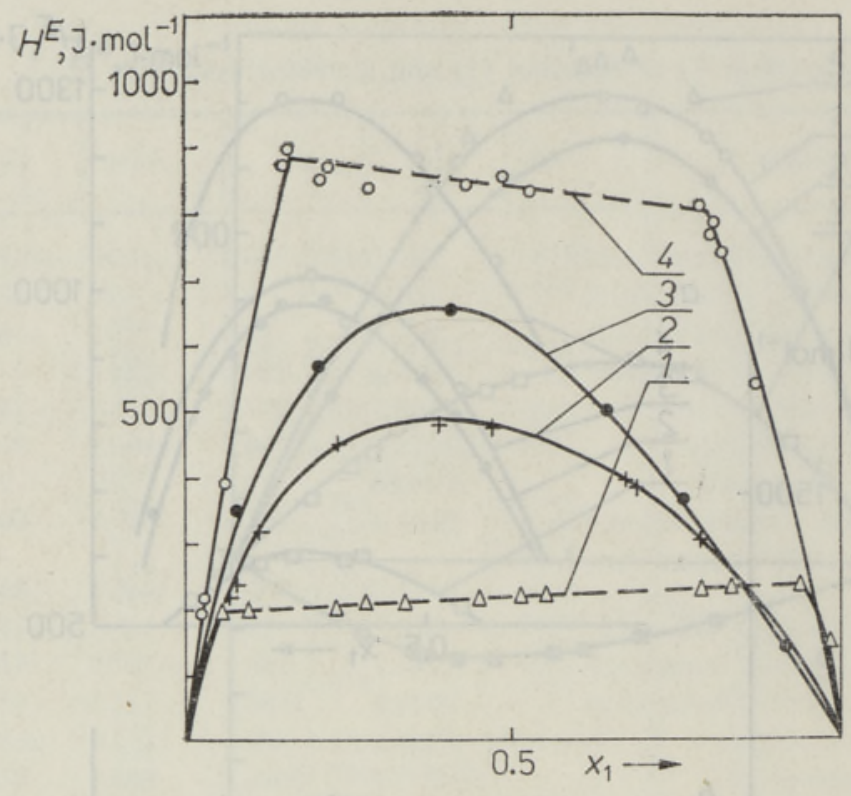

Fig. 4. Excess molar enthalpies at $298.15 \mathrm{~K}$ for mixtures of $x_{1}$ unsaturated hydrocarbons with $\left(1-x_{1}\right)$ dimethyl sulphoxide (lines $\left.1-4\right): \Delta-1$-octene, +-1 -octyne, 1-nonyne, $\mathrm{O}-2$-octyne, $\_-$Eq. (1) with parameters from Table 2 , — — Eq. (2) with parameters from the text.

The $H^{E}$ values for the $n$-alkanol mixtures (Table 1, Nos $13-20$ ) are dependent on the unsaturated hydrocarbon structure much more than on the molecule length of $n$-alkanols.

The typical curves of $H^{E}$ against $x_{1}$ for the $n$-alkanol systems studied are shown in Figs $3 a, b$. Fig. $3 b$ presents the results together with the curves for 1-nonene and 1-nonyne mixtures with 1-butanol taken from our previous work [7]. Not only the shape but also the magnitude of $H^{E}$ is similar to that found in series with the other $n$-alkanols. The $H^{E}$ is positive over the whole mole fraction range and the maximum $H^{E}$ value for all systems occurred in the alcohol-poor region. The positive values of $H^{E}$ result from the breaking of the $\mathrm{H}$-bonds of alkanol which is evident from a sharp rise of $H^{E}$ in the $x_{1} \rightarrow 1$ range. For a given $n$-alkanol $H^{E}$ increases in the order: alkyl cyclopentene $<1$-alkene $<1$-alkyne $<2$-alkyne. It is tempting to associate the different $H^{E}$ values of isomeric $n$-alkyne mixtures with the different interactions of these isomers with $n$-alkanol, taking into account the change in $H^{E}$ in the cyclohexane series.

As noted for the other unsaturated hydrocarbon-alkanol mixtures [7], equation (1) does not represent the experimental results of $H^{E}$ very closely for $x_{1}$ values higher than 0.9 . In the present work each set of results was fitted using equation (1) only in the $x_{1}=0.0-0.9$ range. Data on $H^{E}$ were few for 1-octyne-1-propanol and 2-octyne-1-octanol to be fitted.

In the DMS series (Tabel 1 , Nos $21-24$ ) the $H^{E}$ is positive for all the mixtures and as it can be seen in Fig. 4, the systems containing 1-octene and 2-octyne have a central immiscibility gap. The results in this twophase region are represented by the linear form

$$
H^{E}\left(\mathrm{~J} \cdot \mathrm{mol}^{-1}\right)=b_{0}+b_{1} \mathrm{x}_{1},
$$

where $b_{0}=207.3, b_{1}=31.6, \sigma=2.2$ and $b_{0}=919.8, b_{1}=-178.1, \sigma=20.7$ for 1 -octene and 2-octyne mixtures with DMS respectively. The results for the two homogeneous regions of 2-octyne-DMS were combined and fitted by a smoothing function (1). By simultaneous solution of equations (1) and 
(2) the two-phase region limits were found: 0.17 and 0.79 mole fraction of 2-octyne. In the homogeneous region 1-octene-DMS we have few data on $H^{E}$ to be correlated. The shape of the $H^{E}$ curves for $n$-alkyne is different from that found in the latter series with alkanols. Apparently, the $H^{E}$ maximum shift in the DMS-rich region is the result of the destruction of the $n$-alkyne associate occurring predominantly in this region. The different $H^{E}$ values of the isomeric $n$-alkyne mixtures are due to quite a different interaction of these isomers with DMS and to the capability of 1-alkyne for hydrogen bonding to the solvent, which decreases with the $n$-alkyne molecule length.

\section{REFERENCES}

1. Отса Э. К., Михкельсон В. Я., Кудрявцева Л. С. Теплоты смешения в системах н-алкан-н-алкин-1 // Ж. физ. химин, 1979, 53, № 4, 899-901.

2. Михкельсон В., Кыбу А. Исследование работы колонки со щеточным ротором // Изв. АН ЭССР. Хим., 1980, 29, № 2, 109-112.

3. Эльвельт А., Отса Э., Эйзен О. Физико-химические характеристики изомерных н-октинов и н-нонинов // Изв. АН ЭССР. Хим., 1979, 28, № 4, 287-289.

4. Куус М., Кудрявцева Л., Кирсс Х. Энтальпии смешения изомеров н-октена с некоторыми органическими соединениями // Изв. АН ЭССР. Хим., 1982, 31, № 1, $54-57$.

5. Винк И. О синтезе 1-алкилциклопентенов // Изв. АН ЭССР. Хим., 1988, 37, № 1, $44-46$.

6. Кудрявцева Л., Куус М., Эльвельт А. О межмолекулярных взаимодействиях в системах, содержащих нормальные алкены // Изв. АН ЭССР. Хим., 1983, 32 , № $4,259-267$.

7. Кудрявцева Л., Куус М., Хярсине $H$. Энтальпии смешения и сольватации в системах алифатический углеводород-спирт // Изв. АН ЭССР. Хим., 1987, 36, № 3, 186193.

8. Otsa, E., Kudrjawzewa, L. S., Eisen, O. Thermodynamische Untersuchungen an $n$-Alkan/n-Alkin Systemen. 1. Die Mischungswärmen // Monatsh. Chem., 1980, H. $111,37-42$.

9. Куус М., Кудрявцева Л., Эйзен О. Термодинамические свойства смесей н-октапа с изомерами н-октена. 1. Теплоты смешения // Изв. АН ЭССР. Хим., 1980, 29, № $1,25-31$.

10. Otsa, E., Kudrjawzewa, L. Zur zwischenmolekularen Wechselwirkung in den $n$-Alkine enthaltenden Systemen. Abstracts. 5th Conference on Mixtures of Non-Electrolytes and Intermolecular Interactions, 1983, April 18-22, Halle (GDR).

11. Lam, V. T., Picker, P., Patterson, D., Tancrede, P. Thermodynamic effects of oriental order in chain-molecule mixtures. 1. Heats of mixing of globular and normal alkanes // J. Chem. Soc. Faraday Trans., 1974, 70, 1465-1478.

Academy of Sciences of the Estonian SSR, Institute of Chemistry

Received

Nov. 30,1988

\section{KUDRJAVTSEVA, M. KUUS, Helle KIRSS, I. VINK}

\section{MOLEKULI STRUKTUURI MOJU KULLASTUMATUID SUSIVESINIKKE SISALDAVATE SEGUDE LIIGENTALPIATELE}

Mikrokalorimeetris DAK-1-1 on määratud temperatuuril $298,15 \mathrm{~K}$ liigentalpiad $H^{E}$ 24 binaarse süsteemi jaoks: $n$-heptaan 1-metüültsüklohekseeni ja 1-etüültsüklopenteeniga; n-nonaan 1-butüültsüklopenteeniga; tsükloheksaan 1-metüültsükloheksceni ja cis-4-okteeniga; etüülbenseen 1-okteeni ja l-oktüüniga; metüülbutüülketoon 1-metüültsüklohekseeni, 1-okteeni, 1-oktüüni ja 2-oktüüniga; metüülisobutüülketoon 1-okteeniga; 2-propeen-1-ool 1-okteeniga; 1-propanool 1-oktüüniga; 1-butanool 1-butüültsüklopenteeni, 1-oktüüni ja 2-oktüüniga; 1-oktanool 1-okteeni, 1-oktüüni ja 2-oktüüniga; dimetüülsulfoksiid 1-okteeni, 1-oktüüni, 2-oktüüni ja 1-nonüüniga, Süsteemides dimetüülsulfoksiid-1-okteen ja dimetüülsulfoksiid-2-oktüün on vedel faas kihistunud. Homogeensete lahuste $H E$ sõltuvus kontsentratsioonist on aproksimeeritud Redlichi-Kisteri vōrrandiga, heterogeenscs piirkonnas aga sirge vōrrandiga. On näidatud, et iga lahusti puhul sõltuvad lifgentalpiad küllastumatute süsivesinike molekulide kujust ja suurusest, küllastumuse astmest ja kordse sideme asukohast molekulis. 


\section{ВЛИЯНИЕ МОЛЕКУЛЯРНОИ СТРУКТУРЫ НА ИЗБЫТОЧНЫЕ ЭНТАЛЬПИИ СМЕСЕИ С НЕНАСЫЩЕННЫМИ УГЛЕВОДОРОДАМИ}

В микрокалориметре ДАК-1-1 при 298,15 K определены энтальпии смешения, $H F$, в 24 бинарных системах, образованных 1-метилциклогексеном и 1-этилциклопенгеном с $\boldsymbol{H}$-гептаном, 1-бутилциклопентеном с $\boldsymbol{H}$-нонаном, 1-метилциклогексеном и цис-4-октеном с циклогексаном, 1-октеном и 1-октином с этилбензолом, 1-метилциклогексеном, 1-октеном, 1-октином и 2-октином с метилбутилкетоном, 1-октеном с метилизобутилкетоном, 1-октеном с 2-пропен-1-олом, 1-октином с 1-пропанолом, 1-бутилциклопентеном, 1-октином и 2-октином с 1-бутанолом, 1-октеном, 1-октином, 2-октином с 1-октанолом, 1-октеном, 1-октином, 2-октином и 1-нонином с диметилсульфоксидом (ДМС). В системах, образованных ДМС с 1-октеном и 2-октином, жидкая фаза расслаивается. Концентрационная зависимость $H E$ гомогенных растворов аппроксимирована уравнением Ред.лиха-Кистера, гетерогенной области - уравнением прямой линии. Показано, что избыточные энтальпии смесей данного растворителя с ненасыщенными углеводородами зависят от формы и величины молекул последних, их степени ненасыщенности и положения в них кратной связи. 